\title{
PHRASEOLOGICAL REITERATION OF ENGLISH PHRASEOLOGICAL UNITS DESIGNATING PERSON'S AGE AND THEIR TRANSLATION INTO RUSSIAN
}

\author{
REITERAÇÃO FRASEOLÓGICA DE UNIDADES FRASEOLÓGICAS EM INGLÊS \\ DESIGNANDO A IDADE DA PESSOA E SUA TRADUÇÃO PARA O RUSSO
}

\author{
REITERACIÓN FRASEOLÓGICA DE LAS UNIDADES FRASEOLÓGICAS INGLÉS QUE \\ DESIGNAN LA EDAD DE LA PERSONA YSU TRADUCCIÓN AL RUSO
}

\author{
Plankina Regina MARATOVNA ${ }^{1}$ \\ Arsenteva Elena FRIDRIKHOVNA ${ }^{2}$ \\ Yetzaneth del Valle DIAZ ${ }^{3}$ \\ Natalia Grigorievna MED ${ }^{4}$
}

\begin{abstract}
The article is devoted to the study of one of the types of contextual use of phraseological units (PU) designating age in the English language, and the ways of translating phraseological reiteration into Russian. A short survey of works in question is presented: namely, the experimental study of occasional use of phraseological units by American and native researchers. The aim of the research is to identify the possibility of employing two aspects of phraseological reiteration (repetition of one or more PU components bearing the main meaning load, or repetition of the whole phraseological unit) by the informants - non-native speakers of the English language. Students of third year of Kazan Federal University, future specialists in the field of English, acted as informants. The experiment was carried out at the end of the sixth semester of study, after students specializing in linguistics took a course on the basics of English phraseology. One of the sections of this course is the study of the contextual (everyday and occasional) use of phraseological units, so students were already familiar with the mechanisms of occasional transformations of phraseological units and tested them in the classroom on a number of examples taken from fiction from English and American writers. The ways of adequate translation of phraseological reiteration into Russian under linguistic experimental conditions are also analyzed.
\end{abstract}

KEYWORDS: Phraseological units. Age. Contextual use. Occasional transformation. Phraseological context. Phraseological reiteration. Ways of translation. Adequacy of translation.

RESUMO: $O$ artigo se dedica ao estudo de um dos tipos de uso contextual de unidades fraseológicas (PU) para designar idade na língua inglesa e as formas de tradução da

${ }^{1}$ Kazan Federal University (KPFU), Kazan - Russia. Senior Lecturer of the Department of Romance and Germanic Philology, Institute of Philology and Intercultural Communication. $\mathrm{PhD}$ in Philology. ORCID: https://orcid.org/0000-0001-7238-681X. E-mail: regina_pl@mail.ru

${ }^{2}$ Kazan Federal University (KPFU), Kazan - Russia. Professor of the Department of Romance and Germanic Philology, Institute of Philology and Intercultural Communication. Doctor of Philology. ORCID: https://orcid.org/0000-0002-3700-2670. Email: elenaarsentiewa@mail.ru

${ }^{3}$ Kazan Federal University (KPFU), Kazan - Russia. Lecturer at the Department of Romance and Germanic Philology, Institute of Philology and Intercultural Communication. PhD in Philology. ORCID: https://orcid.org/0000-0003-0488-7510. E-mail: yetzaneth79@gmail.com

${ }^{4}$ Saint Petersburg State University (SPBU), Saint Petersburg - Russia. Professor of the Department of Romance Philology. Doctor of Philology. ORCID: https://orcid.org/0000-0002-8232-3481. E-mail: natalia_med@mail.ru

Rev. EntreLínguas, Araraquara, v. 7, n. esp. 1, p. 144-153, fev. 2021

e-ISSN: 2447-3529 
reiteração fraseológica para o russo. É apresentado um breve levantamento das obras em questão: a saber, o estudo experimental do uso ocasional de unidades fraseológicas por pesquisadores americanos e nativos. O objetivo da pesquisa é identificar a possibilidade de empregar dois aspectos da reiteração fraseológica (repetição de um ou mais componentes do PU que carregam a carga de significado principal, ou repetição de toda a unidade fraseológica) pelos informantes - falantes não nativos do inglês língua. Alunos do terceiro ano da Universidade Federal de Kazan, futuros especialistas na área de inglês, atuaram como informantes. $O$ experimento foi realizado no final do sexto semestre letivo, após os alunos do curso de linguística cursarem noções básicas de fraseologia do inglês. Uma das seções deste curso é o estudo do uso contextual (cotidiano e ocasional) de unidades fraseológicas, para que os alunos já estivessem familiarizados com os mecanismos de transformações ocasionais de unidades fraseológicas e os testassem em sala de aula com uma série de exemplos retirados de ficção de escritores ingleses e americanos. As formas de tradução adequada da reiteração fraseológica para o russo em condições experimentais linguísticas também são analisadas.

PALAVRAS-CHAVE: Unidades fraseológicas. Idade. Uso contextual. Transformação ocasional. Contexto fraseológico. Reiteração fraseológica. Formas de tradução. Adequação da tradução.

RESUMEN: El artículo está dedicado al estudio de uno de los tipos de uso contextual de unidades fraseológicas (UP) que designan la edad en el idioma inglés, y las formas de traducción de la reiteración fraseológica al ruso. Se presenta una breve reseña de las obras en cuestión: a saber, el estudio experimental del uso ocasional de unidades fraseológicas por investigadores estadounidenses y nativos. El objetivo de la investigación es identificar la posibilidad de emplear dos aspectos de reiteración fraseológica (repetición de uno o más componentes de PU que soportan la carga de significado principal, o repetición de toda la unidad fraseológica) por parte de los informantes - hablantes no nativos del inglés. idioma. Los estudiantes de tercer año de la Universidad Federal de Kazán, futuros especialistas en el campo del inglés, actuaron como informantes. El experimento se llevó a cabo al final del sexto semestre de estudio, luego de que estudiantes de la especialización en lingüística tomaran un curso sobre los conceptos básicos de fraseología inglesa. Una de las secciones de este curso es el estudio del uso contextual (cotidiano y ocasional) de unidades fraseológicas, por lo que los estudiantes ya estaban familiarizados con los mecanismos de transformaciones ocasionales de unidades fraseológicas y los probaron en el aula con una serie de ejemplos tomados de ficción de escritores ingleses y estadounidenses. También se analizan las formas de traducción adecuada de la reiteración fraseológica al ruso en condiciones lingüísticas experimentales.

PALABRAS CLAVE: Unidades fraseológicas. Edad. Uso contextual. Transformación ocasional. Contexto fraseológico. Reiteración fraseológica. Formas de traducción. Adecuación de la traducción.

\section{Introduction}

The study of the contextual use of phraseological units has been in the focus of attention of both Russian and foreign scientists for rather a long period of time. Significant success has been achieved over this period of time. A.V. Kunin distinguished between the concepts of 
"everyday use" and "occasional use" of phraseological units, laid the foundations for the study of occasional changes in phraseological units, and revealed three types of phraseological context (KUNIN, 1970). Russian and foreign phraseologists identified the main types of occasional transformations (modifications) of phraseological units of a systemic nature, revealed the mechanisms of their creation, as well as the stylistic effect of each type of transformations, characterized the features of the internal and external plan of phraseological units that determine their active creative potential. Some valuable information about evaluative component of meaning can be found from illustrative examples used in entries of phraseological dictionaries (AYUPOVA, 2015, p. 284). Most scholars distinguish two main types of transformations of phraseological units in context - semantic and structural-semantic, the number of types of occasional transformations of phraseological units analyzed, varies in dissertations and articles from four to thirteen (ABDULLINA, 2007). The phraseological material of one and two or more languages was analyzed.

The late eighties and the beginning of the nineties of the twentieth century was marked by the beginning of an experimental study of the transformational potential of phraseological units. For the first time, an American researcher, R.G. Gibbs and his colleagues at the University of California in Santa Cruz in the late eighties of the twentieth century turned to the experimental study of idioms in discourse. They convincingly proved the fact that for native English speakers, the metaphors that underlie the figurative rethinking of English idioms are lively and form part of their cognitive thinking. The experimental studies of American scientists were continued by Russian phraseologists, mainly representatives of Kazan Linguistic School. It should be noted that Russian scientists conducted a linguistic experiment with both native speakers and non-native speakers. The results of the experiment made it possible to identify the most characteristic types of occasional transformations of phraseological units, allowing to determine the key component /components of phraseological units (GIBBS, 1990). to substantiate the possibilities of the correct use of the mechanism of transformation of phraseological units by both native and non-native speakers of different structural languages, to identify the importance of linguistic and extralinguistic factors in the implementation of various types of occasional transformations phraseological units by native speakers and nonnative speakers of these languages (ZINATULLINA, 2013). "Constant studies of functioning of native and non-native languages, the process of teaching and cross-cultural communication demands the skillful use of languages" (SALIEVA; SAFINA 2019, p. 535). 


\title{
Methods
}

The results of the linguistic experiment conducted by the scientists of Kazan Linguistic School permit, in particular, to determine the necessary requirements for the successful use of different types of occasional use of phraseological units both by native speakers and non-native speakers. These include:

“- high (not lower than Higher Intermediate, preferably Advanced) level of language proficiency;

- understanding and mastery of the mechanism for creating various types of transformations of phraseological units;

- developed imaginative and logical thinking;

- creative attitude to the language;

- high level of intellectual development, including knowledge of the world historical heritage;

- historically prevailing attitude of native speakers to the language as an inexhaustible source of its creative use;

- the centuries-old tradition of language games" (MATVEEVA, 2017, p. 183).

\begin{abstract}
"Transformed variants of phraseological units are studied in works of the following linguists: Ye.F. Arsenteva (2009), A.F.Artjomova (2009), R.A. Ayupova (2012), A.N. Baranov and D.O.Dobrovol'skij (2006), A.S. Gadakchyan (2013), A.V. Kunin (1972), A.M. Melerovich and V.M.Mokienko (1999), L.K. Bairamova (2013), R.N. Salieva (2009; 2013), R.A. Safina (2013), Ye.Yu. Semushina (2013) and others" (SALIEVA; KONOPLEVA; MIRGALIMOVA, 2016, p. 58).
\end{abstract}

The goal of our linguistic experiment was to identify the possibility of using the correct mechanism for transforming English phraseological units denoting a person's age, and their adequate translation into Russian by non-native speakers of English. The request for the translation is carried out as part of a linguistic experiment for the first time. We conducted a comprehensive experiment, which, in turn, combines different types of experiments: natural, open, transformative and mental. Third-year students of Kazan Federal University, future specialists in the field of English, acted as informants. The design of the experiment was a series of steps: identifying the purpose and hypotheses of the experiment, creating the necessary conditions for obtaining reliable results, accurate statement of the problem, and correct quantification of the results. First of all, we determined the purpose of the experiment: to identify the main factors underlying the correct creation of occasional transformations of 
English phraseological units and their adequate translation into Russian by non-native speakers of English. A sufficiently high level of knowledge of English by non-native speakers, understanding by the informants of the mechanism of phraseological reiteration and methods of adequate translation of examples into Russian, and a well-developed logical and figurative thinking were identified as three main factors for the successful fulfillment of the experiment this was the hypothesis of the experiment.

Here is the list of twelve English PU denoting the age of a person used for the experiment:

1. bear (carry) one's age well- хорошо выглядеть для своих лет, выглядеть моложе своих лет;

2. fretting cares make gray hairs $\sim$ не работа старит, а забота;

3. the Darby and Joan club - клуб для пожилых людей;

4. rob the cradle aмер. разг. шутл. - «обокрасть колыбель», жениться на ком-либо или выйти замуж за кого-либо значительно моложе себя, флиртовать с кем-либо значительно моложе себя;

5. an old dog barks not in vain - «старый пес не будет напрасно лаять»;

6. between grass and hay амер. - в юношеском возрасте;

7. <as> old as the hills - очень старый, древний;

8. does your mother know you're out? разг. ирон. у тебя молоко на губах не обсохло, тебе еще в коротеньких штанишках ходить;

9. mutton dressed <up> as lamb неодобр. - молодящаяся старушка;

10. show one's years - сгибаться под тяжестью лет, стареть;

11. a wise man has wise children амер. - яблоко от яблони недалеко падает, ребенок наследует черты родителей;

12. the surest sign of age is loneliness амер. - одиночество - верный признак старости.

Phraseological reiteration is one way of occasional use of PU. It consists in repeating the entire PU or component / components of PU within the phraseological context. This type of transformation of phraseological units does not belong to complex contextual modifications of $\mathrm{PU}$, its main purpose is to strengthen the meaning and expressivity of the phraseological context. 
Besides linguistic experiment, phraseological description as one of the methods suggested by Professor A.V. Kunin, as well as observation method and calculation methodology were used. Comparative method is also very important while analyzing the material of two languages.

\section{Results and discussion}

Creation of examples of phraseological reiteration did not cause any particular difficulties for our participants of the experiment (BYJYK, 2016). We note, however, that the repetition of the entire PU within the phraseological context was used by informants in $28 \%$ of cases, all other examples were connected with the repetition of one or more components of PU.

The use of dialogue is the most "fertile environment" for the reiteration of all PU, which the following examples clearly demonstrate:

- She begins to show her years.

- Yes, I see. When my auntie was in her age, she began to show her years too.

The phraseological method of translation is the transfer of this English phraseological unit into Russian using the analogue "bend under the weight of years" («сгибаться под тяжестью лет»), which was successfully used by the informant, while the phraseological reiteration is also present in the Russian translation:

- Она начинает сгибаться под тяжестью лет.

- Да, я вижу. Когда моя тетушка была в ее возрасте, она тоже начала сгибаться под тяжестью лет.

Another possible way of translation is using the Russian lexeme «стареть» (“grow old):

- Да, я вижу. Когда моя тетушка была в ее возрасте, она тоже начала стареть.

The phraseologism "between grass and hay" - "in youth" («в юношеском возрасте») was used twice in the English context. When transferring it to Russian, the informant in the first case used this Russian correspondence introduced by the parenthesis, in the second case he successfully replaced it with a descriptive translation, but the meaning of the PU was fully preserved:

- He is a young boy. As they say, between grass and hay.

- I wish I were between grass and hay! 
- Он молодой парень. Как говорят, в юношеском возрасте.

- Как бы я хотел быть таким же молодым!

Proverbial pictures of the compared languages in a certain degree contain knowledge of the same side of reality (TARASOVA; MUKHARLYAMOVA, 2014, p. 196). In the following example, the informant showed not only the ability to use the phraseological reiteration of the PU in the English context, but also used two translation methods: phraseological, with the help of a well-known Russian proverb, and non-phraseological, namely, descriptive:

- I wish he were my dad. You know, a wise man has wise children.

- Oh, it's just because of genetics: and wise man has wise children.

- Как жаль, что он не мой отец! Ты же знаешь, ребенок наследует черты родителей.

- Да это просто генетика срабатывает: яблоко от яблони недалеко падает.

The PU "mutton dressed <up> as lamb" - "an old woman trying to look younger" («молодящаяся старушка») with pejorative emotion of disapproval was also used in the dialogue to create phraseological repetition. It is considered to be successful to use the colloquial lexeme «рядиться» - «одеваться нарядно» (OZHEGOV, 1978:636). (“dress up” "dress smartly") in order to avoid in this case, the undesirable repetition of the Russian correspondence “an old woman trying to look younger” («молодящаяся старушка»):

- Ha-ha! Look at this old lady, she is a mutton dressed up as lamb.

- This mutton dressed up as lamb looks better than you!

-Ха-ха-ха! Посмотри на эту пожилую леди, рядящуюся под молодушку!

- Эта молодящаяся старушка выглядит лучше тебя!

In the last example presented, the reiteration of the entire PU "as old as hills" ("very old, ancient") is used in relation to an inanimate object, which is quite acceptable, the phraseological correspondence in this case is the analogue «старо как мир» ("old as the world"). However, the informant was able to choose a more suitable version of the lexical translation, since it is about information, and according to the norms of lexical valency and collocability, the most acceptable combination is «устаревшая информация» (“outdated information"):

- Your information is as old as hills. 
- It can't be as old as hills, it just happened yesterday.

- Твоя информация устарела.

- Она не может быть устаревшей, это случилось только вчера.

As already noted, the form of dialogue remains natural, while one speaker uses the full form of the PU, and the other, picking up the thought, extracts from the PU the component or components that are most suitable for expressing his intention.

So, in the following example, the informant leaves two of the three components, by replacing them (literally: her years, that is, age) with the pronoun "him" («его»):

- Isn't it ridiculous! She is trying so hard not to show her years.

- Year. No matter how hard she is trying to conceal it, we still see her years perfectly well even through her extravagant make-up.

- Ну не смешно ли? Она так старается скрыть свой возраст!

- Да, но как бы она не старалась, мы видим его даже сквозь ее экстравагантный макияж.

\section{Summary}

So, phraseological reiteration as a type of occasional use of phraseological units did not cause noticeable difficulties during the experiment. The number of examples of its use in dialogues significantly exceeded the number of those in monologues (more than $70 \%$ ). When repeating one or more components of PU, repetition of components carrying the main semantic load (key components) was observed. The examples created by non-native speakers have shown that successful use of phraseological reiteration helps to increase the expressivity and emotiveness of the created phraseological context by enhancing the meaning of the PU. All examples of translation also indicate that not only the meaning of the created phraseological context is adequately conveyed, but also both Russian phraseological and non-phraseological counterparts of English PU can be applied to.

\section{Conclusions}

The implementation of linguistic experiment in the creation of phraseological reiteration of English phraseological units designating age by non-native speakers was based on the systematic nature of this type of occasional transformations of phraseological units. The most 
important factor of its successful implementation is the proper design of the experiment. The analysis of the ways of translation of the English examples created by Russian native speakers into Russian shows two possible ways of their translation - with the help of phraseological and non-phraseological counterparts. In the majority of cases it was possible to reproduce phraseological reiteration also in Russian. The results of the experiment clearly show the possibility of adequate transference of the used type of transformation of English phraseological units in compliance with the norms of the Russian language in most cases.

ACKNOWLEDGEMENTS: The work is performed according to the Russian Government Program of Competitive Growth of Kazan Federal University.

\section{REFERENCES}

\section{ABDULLINA, A. R. Kontekstual'nye transformacii frazeologicheskih edinic $\mathbf{v}$} anglijskom i russkom yazykah: dis. kand. filol. nauk: 10.02.20 /Abdullina Ajsylu Ravilevna. Kazan, 2007. 167 p.

AYUPOVA, R. A. Illustrative Material in the Structure of Phraseographic Entries. Asian Social Science, v. 11, n. 7, p. 284-289, 2015.

BYJYK, Y. A. Frazeologicheskie edinicy s kolorativnym komponentom $\mathbf{v}$ anglijskom i tureckom yazykah: dis. kand. filol. nauk: 10.02.20 /Byjyk YAna Arturovna. Kazan, 2016. $160 \mathrm{p}$.

GIBBS, R. W.; O'BRIEN, J. Idioms and mental imagery: the metaphorical motivation for idiomatic meaning. Cognition, p. 35-68, 1990.

KUNIN, A. V. Anglijskaya frazeologiya (teoreticheskij kurs). Moscow: Vysshaya shkola. 344 s. 1970.344 p.

MATVEEVA, Y. O. Frazeologicheskie edinicy s muzykal'nym terminom v anglijskom i russkom yazykah: dis. kand. filol. nauk: 10.02.20 /Matveeva YUliya Olegovna. Kazan, 2017. 183 p.

OZHEGOV, S. I. Slovar' russkogo yazyka. Moscow: Russkij yazyk, 1978. 636 p.

SALIEVA, R. N.; SAFINA, R. A. Transformed phraseological units in mass media headings in English and Russian languages. The European Proceedings of Social and Behavioural Sciences, p. 535-543, 2019.

SALIEVA, R. N.; KONOPLEVA, N. V.; MIRGALIMOVA, L. M. Phraseological units in American and Russian governmental blogs. XLinguae Journal, v. 9, n. 4, p. 58-67, 2016. 
TARASOVA, F. H.; MUKHARLYAMOVA, L. R. Modelling of phraseosemantic groups in the system of the Tatar, Russian and English paroemias (on the examples of proverbs and sayings with "food" component). Journal of Language and Literature, v .5, n. 3, p. 196$202,2014$.

ZINATULLINA, L.M. Adverbial'nye frazeologicheskie edinicy v anglijskom i russkom yazykah: dis. ... kand. filol. nauk: 10.02.20 / Zinatullina Liliya Muharlyamovna. Kazan, 2013. 170 p.

\section{How to reference this article}

MARATOVNA, P. R.; FRIDRIKHOVNA, A. E.; DIAZ, Y. V.; MED, N. G. Phraseological reiteration of English phraseological units designating person's age and their translation into Russian. Rev. EntreLínguas, Araraquara, v. 7, n. esp. 1, p. 144-153, fev. 2021. e-ISSN: 24473529. DOI: https://doi.org/10.29051/el.v7iEsp1.14881

Submitted: $28 / 10 / 2020$

Required revisions: $19 / 12 / 2020$

Approved: $13 / 01 / 2021$

Published: 28/02/2021 